\title{
Spatial and Social Inequality in Communist Countries and in the First Period of the Transformation Process to a Market Economy: The Example of Hungary
}

\author{
Peter Meusburger \\ Department of Geography, University of Heidelberg, D-69120 Heidelberg, Germany
}

\begin{abstract}
This paper argues that Marxism created new forms of inequality but was not able to abolish many of the old inequalities inherited from capitalism. The legacy of history, social and spatial division of labor, the hierarchy of control in large organizations and power relations proved to be stronger than the Marxist ideology, the abolishment of private ownership, the nationalization of the economy, central planning and all other instruments of Marxism that were meant to create equality and a "new socialist human being". The author claims that an authoritarian and dogmatic ideology such as Marxism inevitably creates structures of organization where power and decision-making are extremely centralized. Furthermore the so-called "administrative allocation" of scarce resources and the way in which the leading party members were recruited contributed to the centralization of power and high-ranking decision making. In this bureaucratic competition for scarce resources the "periphery" had almost no chance. The image of "greater equality in socialism" was constructed by propaganda and by the communist monopoly over mass media, scientific publications, statistics and public education. In the empirical part the author discusses three examples of inequalities in communist systems: the spatial concentration of highly qualified jobs, gender disparities in the labor market and the inequalities experienced by gypsies. The third chapter deals with the new spatial patterns of inequality emerging in the first period of the transformation process to a market economy.
\end{abstract}

Key words: spatial and social inequality, Marxism, Hungary, centrally planned economy, female labor force participation, level of education, ethnic minorities

\section{Spatial and Social Inequality in Com- munist States-A Capitalist Legacy, an Historical Accident or a System Immanent Feature of Marxism?}

Research on the effects of the transformation process from a centrally planned to a market economy is complicated by the fact that the real situation at the beginning of the process is not known well enough. Since the reduction of inequalities is an important principle of MarxismLeninism and plays a great role in Marxist ideology and communist identity, existing inequalities in communist systems were tabooed, denied, kept secret as long as possible (Bleek and Mertens 1994) or were explained as a legacy of capitalism. In all communist countries there was an incredible discrepancy between reality and ideology. "Building socialism turns into painting socialism ... This juxtaposition of the real and the imaginary is not confined to the exceptional. It is part and parcel of factory life, the union elections, the production conferences, competition among socialist brigades, and the communist shifts. Because it is embedded in real practices, the pretense unwittingly assumes a life of its own ... Painting over the sordid realities of socialism is simultaneously the painting of an appearance of higher brightness, efficiency, and justice. Socialism becomes an elaborate game of pretense that everyone sees through but that everyone is compelled to play. It is an intermingling of a desultory reality and fabricated appearance in which the appearance takesona reality of its own" (Burawoy 1989: 15-16).

A second difficulty lies in the fact that most inequalities in the communist systems have been studied by comparing states or large prov- 
inces and that public statistics were aggregated in a way that concealed the real range of disparities.

\section{Layers of spatial inequalities in communist countries}

There are four layers of spatial patterns to be analyzed when studying social inequalities in former communist countries. The first layer comprises the disparities created by physical geographical factors (climate, soils, mineral resources, etc.) which favor some regions and disadvantage others. Uneven development in the USSR was explained "with enormous internal variations in resource endowment... Distance exacerbated by severe winter climate makes for the isolation of some areas and the sheer physical difficulty of obtaining goods and personnel where they are needed" (Smith 1979: 156).

The second layer consists of all disparities created by historical influences in pre-communist times. Various historical facts determine how regions, locations and sites are perceived and evaluated by society and whether or when these places have had contact with important innovations. Since most of the epoch-making social and economic innovations in Hungary, such as Christianity (economic and cultural influence of monasteries), Roman law, enlightenment, abolition of serfdom, spread of literacy, industrialization and foreign investment (especially since 1989) came from the west, Hungary traditionally experienced a westeast dichotomy and was crossed by zones of centuries-old cultural and economic borders. Historically speaking, some of the western regions of Hungary (northern part of Transdanubia) including the later capital of Budapest, adopted many important innovations and developments much earlier than the eastern parts of Hungary because they had early exposure to them. The early or late adoption of innovations was connected to unequal spatial distribution of human resources, economic traditions and differing spatial extensions of contact fields. These relationships are difficult to analyze quantitatively, but they can be understood and explained hermeneutically.

The third layer of inequalities results from the division of labor, from professionalization and the bureaucratization of labor relations. The vertical and horizontal division of labor leads to a spatial concentration of power and knowledge in all political and economic systems (Meusburger 1995a). It causes centralperipheral and urban-rural disparities and determines the hierarchy of the settlement system. Smith (1979:353) was one of the first to recognize that "large, hierarchically structured organizations can generate their own momentum towards uneven development, under socialism as well as capitalism".

The fourth layer represents the impact of the communist period. Inequalities created by Marxism or centrally planned economies have hardly been discussed, neither theoretically nor empirically. This is why this paper gives greater attention to the fourth layer than to the other three, which are more well known.

When the first details of social inequalities in the communist states became public in the 1970's (Andorka 1976, Mickiewicz 1973; Smith 1979, Schroeder 1973; Zwick 1976), it was widely accepted that these inequalities either belonged to the historical legacy of capitalism or were the result of the distortion or perversion of Marxism by Stalinism. The presumption prevailed that disparities in living standards might be equalized by central dictate or an efficient and just allocation of resources. Very few authors (e.g. Gentsch 1992) argued that marxist ideology itself creates inequalities.

Today, we know that Marxism created new forms of inequality but was not able to abolish many of the old inequalities. The former centers of power (control hierarchies) and the former rural peripheries more or less kept their functions in the communist system. Expensive residential areas of the former upper class kept their status and housed the new communist "elite". The new impacts of communist planning policy (large industrial combines, new "socialist cities") followed the already existing spatial pattern, some of them even strengthening the central-peripheral disparities.

\section{Could social and spatial inequality be avoided in a "truly" Marxist system?}

Academic discussions about the basic concepts of Marxism are difficult for various 
reasons. First, there is no generally accepted Marxist theory. If somebody relies directly on the writings of Marx which contain a large number of internal contradictions and false prognoses he or she will be accused of adhering to a naive Marxism by "modern" Marxists (e.g., R. Peet, 1977a, 1977b, 1991; Harvey 1973, 1977, 1985). The majority of Marxist scientists preferred to analyze the capitalist system but they remained remarkably vague as to how the ideal communist society of the future or a truly Marxist developed economy should look and function.

Nevertheless, most Marxist authors claim that social and spatial inequalities, social injustices and social classes are inherent in the capitalist mode of production (Peet 1977b: 112) and that they will disappear in a truly Marxist society. They maintain that certain features of a capitalist economy are instrumental in promoting uneven development and that some form of socialism is a necessary condition for an equal society (Smith 1979: 337, 340). Many Marxists still argue that great inequalities of power are mainly caused by ownership of capital and land. "Those who own capital and land (including its natural resources) control the means of production" (Smith 1979: 338). In their opinion the "State Socialism" (=another term for the political-institutional structure of former communist countries) experienced in Central and Eastern Europe has nothing to do with "pure" Marxism.

The false notion that inequalities will fade away in a purely Marxist system results from some of Marx's main errors. Marx and even modern Marxists (e.g. Braverman 1974) expected a reduction in the division of labor and a de-qualification of the labor force in the future. For the same reasons Marxist theory underestimated the importance of knowledge, skills and competence in developed economies, and the persistence of local knowledge, local values, contact fields and cultural traditions. On the other side, they overestimated the importance of private property for uneven development and social inequality. Contrary to Marxist expectations, the division of labor, which leads to numerous social and spatial inequalities, is unavoidable in any developed economy, regardless of whether it is communist or capitalist. "Just as under capitalism, the highest-level control functions will be exercised from the capital city. This is where the highest-status (and best-paid) jobs will be found" (Smith 1979: 341). No Marxist theorist was ever able to explain how a large industrial enterprise could be managed without a vertical division of labor, without a control hierarchy and without highly qualified experts.

My first argument is that the legacy of history, social and spatial division of labor, longstanding cultural and economic traditions, ethnicity, civic norms, social values, time lags in the diffusion of industrialization and literacy, differences in the spatial extension of contact fields and regional differences in economic and political history had a much stronger influence on the persistence of spatial inequalities than Marxism expected. Decades of Marxist policy such as expropriation, abolition of private ownership, nationalization of the economy, central planning, central allocation of resources, indoctrination (monopoly of information and education) and all other instruments of Marxism that were meant to create equality and a "new socialist human being" had little impact on the traditional spatial structures of social and economic inequality. Smith (1979: 157) was one of the first to recognize "that there may be quite a resemblance between both the reality of regional inequality and the reasons for it under capitalism and socialism".

My second argument is that at least two categories of social and spatial inequalities in communist countries cannot be dismissed as the historical legacy of capitalism or a distortion of "pure" Marxism. As soon as Marxism abandons the academic playground and seizes power it inevitably becomes dogmatic and authoritarian. The caretakers of dogmas, "revealed knowledge" and "historical truths" always tend to the centralization of power. An authoritarian and dogmatic ideology such as Marxism inevitably creates structures of organization in which decision-making and skills are extremely centralized. L. Gentsch (1992: 133147) has presented convincing arguments that extreme centralization of decision making and the authoritarian and dogmatic structures of the communist system can be traced directly 
back to Karl Marx. His claim to have an absolute, historical truth allowed no discussion of Marxist dogmas and no alternative interpretations. It opposed individual thinking and alternative solutions. No leader could be selected for any important position without the permission of the party. The authoritarian behavior pattern of Marx and Lenin led to authoritarian organizational structures in the party's statutes, in the party's laws, and in all political organizations and institutions, from the day-care center and the organization of an industrial state firm to the central committee of the party.

There was a strong centralization of power within the communist party in the days of Marx and Engels and long before the distortion of Marxism through Lenin and Stalin. The cadres and planners in the top ranks of the communist hierarchy had to decide about almost everything, including the recruitment of party members, the distribution of goods, investment, infrastructure and resources. Marx was fully aware of this centralization of power. He believed that the conflict between proletariat and bourgeoisie would first require a strict centralization of decisions, but that the state would wither away once power was attained by the proletariat. Marx was heavily criticized by his anarchist opponents for his naive conclusions. Bakunin clearly predicted that a classless society under Marx's state communism was not possible. According to Bakunin $(1984,12)$ the centrally planned economy will lead to a new class (nomenclature) and to a new hierarchy. $\mathrm{He}$ predicted that a small minority, claiming to possess the absolute knowledge and historical truth, will rule over a large majority, but he never explained the way in which the system of anarchy proposed by him would manage modern industrial enterprises.

Bakunin was remarkably prophetic concerning the so-called nomenclature. In communist Hungary the nomenclature, which made all the important decisions in politics, economy, administration and culture, comprised only 0.29 percent of the total labor force (1983) and the first level of the communist cadres included only 2,300 persons, or 0.05 percent of the work force (Harcsa 1995). All strategically important political, economic, administrative, scientific, and cultural decisions were placed in the hands of one single hierarchy, the party. There was only one single access to resources, namely via the party. "The continuous party control keeps the goal-setting and goal-completing functions together, protects the priority of politics over the economy and the administration, and restrains the expert intelligence who would normally seek expansion of their own power" (Konrád and Szelényi 1978: 273). Never before in history was so much power concentrated in the hands of so few than in the communist period. Even in feudal times approximately 46 percent of the Hungarian population (outside Croatia) belonged to the nobility (Görlich 1965: 297).

In the communist centrally-planned economy, the monopolization of political, economic, administrative and cultural power through a very small leadership, the way in which the nomenclature was recruited, and the so-called "administrative allocation" of (always scarce) resources led to an extreme spatial concentration of workplaces for high-ranking decisionmakers and highly qualified experts in the capital city and in a few provincial capitals (Figure 1). Marxist theorists have traced spatial concentration processes primarily to the capitalist mode of production (competition in the market economy, centralization of capital, development of monopolies) without considering that the centralization of power is typical and unavoidable in Marxism.

A second group of system-immanent inequalities were a result of the goals of communist regional policy, which privileged large urban agglomerations, large industrial combines and "new socialist cities" for ideological reasons. Large cities, heavy industry and large enterprises were regarded as symbols of socialist progress and as showpieces of the superior Marxist system, while the rural periphery was a symbol of the past and the backyard of socialism, neglected and disadvantaged by the administrative allocation of resources. The "center" not only planned and decided, but also collected the surplus and regulated the distribution of goods and resources. The initial industrialization "was accomplished very much at the expense of the countryside, from which the 


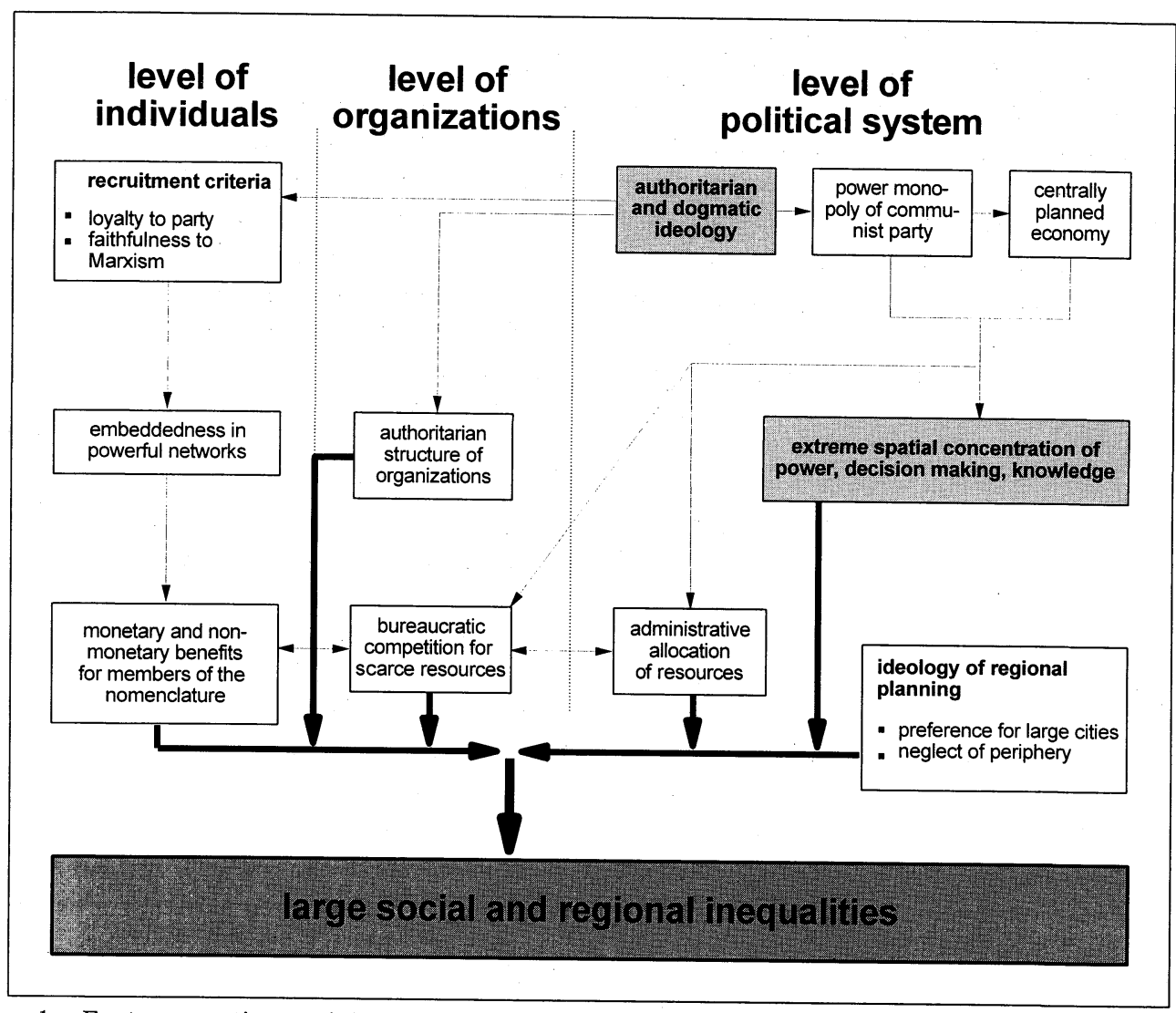

Figure 1. Factors creating social and spatial inequalities in Marxist systems (Design: Peter Meusburger).

surplus for investment was extracted with a degree of ruthlessness that matched the worst excesses of capitalist exploitation" (Smith 1979: 166).

The central administration of the state controlled and dominated the state enterprises, and the state enterprises exercised dominance and control over the communities. Local communities, particularly the smaller ones and those near large state enterprises were paralyzed and dominated in this hierarchy of power (Pickles 1995: 118). In orthodox socialist systems and under such power relations and conditions of one-sided dependency, indigenous development in rural areas was unthinkable. The dependencies of the periphery on the center existing in communist systems can be described with the same words used by Marxist authors analyzing the relations between industrialized and developing countries. "In Wallerstein's model of surplus transfer (wallenstein 1979), actors in the core... use state power deliberately and persistently to weaken (underdevelop) the periphery" (Corbridge 1989: 227). In an economy of scarcity, the administrative allocation of resources was a question of power relations; it showed a trickle-down effect from the top to the bottom of the settlement hierarchy. Most financial resources remained in the higher ranks of the central place hierarchy and for prestigious projects of the communist system. Very few resources arrived at the bottom of the settlement system. Cities and villages had no political and financial autonomy and were completely dependent on the party and the central administration.

A spatial centralization of power and knowledge is also well known in market economies (Meusburger 1995a), but the forces centralizing power and knowledge differ in the two political systems. In a market economy any enterprise is more or less free to choose the locations of its production units, sales offices and headquarters. It can buy spare goods wherever it wants 
and can hire personnel from the labor market. These decisions depend on well-known location factors and market mechanisms: wage differences, consumer location, transport costs and the importance of face-to-face contacts with decision makers of other institutions. In branches facing high competition and uncertainty (e.g. banking), headquarters (places of knowledge and power) are strongly centralized in a few large cities, and in other branches the location of the decision-making is more dispersed. In a market economy the independence and the autonomy of a firm depends largely on its economic success, competitiveness and financial resources. The greater the system's competence, knowledge, information, experience, skills and resources, the higher its autonomy. In a market economy many successful and competitive firms are independent from the government or the political parties.

On the contrary, in an orthodox communist system or a centrally planned economy, all social systems such as firms and institutions are integrated in one single hierarchy, the communist party. The goals and plans for all systems are formulated in the "center", and the distribution of resources is regulated by the "center". In an orthodox communist system, state-enterprises, cooperatives and other institutions had almost no autonomy to formulate their goals or to change their products or plans. All important decisions were made in the highest echelons of the party and planning institutions. If a state-enterprise was given a certain degree of autonomy, it could be taken away by the nomenclature on short notice.

The forces leading to a spatial centralization of power and knowledge in communist systems worked not only on the system level but also on the individual level (Figure 1). In the orthodox communist system loyalty to the MarxistLeninist ideology, faithfulness to the party and embeddedness in powerful networks were the most important criteria for personal promotion and allocation of resources. Leaders of stateenterprises were almost exclusively recruited by their loyalty to the party and by their proletarian origin. A certain amount of "indispensable reactionaries" were needed for their skills and competence only in the ministries and cen- tral planning institutions (Lengyel 1995: 256). In the reform period, when the economic disaster of orthodox communist policy was openly admitted, the relationship between the two recruitment criteria "political responsibility" and "professional competence and skills" altered slightly (Lengyel 1995).

As long as persons are promoted primarily according to their loyalty and faithfulness to an ideology, the relevant person is very dependent on networks within the party confirming his or her loyalty. In order to keep one's position or to get promoted, these networks (the most valuable social capital in a socialist system) had to be cared for very intensely by frequent face-toface contacts and a constant, mutual exchange of favors and privileges. In market systems, frequent face-to-face contacts between important decision-makers are only necessary in some branches in order to cope with the uncertainty of competition. In centrally planned economies close face-to-face contacts and good relations to the powerful cadres were necessary for all party members, leaders of state enterprises, cooperatives and cultural institutions to maintain their status, to prove their loyalty and to have access to the administrative allocation of goods. In market economies power is divided between various institutions and a large number of powerful social networks which compete with each other. The individual has a choice, he or she is not completely dependent on one system and can found his or her own firm or establish his or her own network. In communist states there was only one hierarchy of power. Fractionalism was condemned and outside the party there was no way to access resources, promotion or privileges. Both systems tend towards a spatial centralization of high-level decision makers, but the extent and reasons for centralization are different.

Szelényi (1978: 63-66; 1983: 6) offered ample empirical evidence to show that in state socialist societies the administrative allocation of scarce goods and services (financial resources, houses, jobs, infrastructure, health services, recreation) favored the more well-to-do. Communist redistributive mechanisms created new social and spatial inequalities which increased during the socialist period. A number of inves- 
tigations have shown that new state housing was allocated systematically to the higher income groups and not to the proletariat. The housing policy also increased effective income inequalities, "making the real income inequalities greater than the wage-fixing authorities thought necessary for purposes of productive incentive and reward" (Szelényi 1983: 74). "White collar workers received almost 50 percent more per capita from non-cash benefits than industrial workers; high managers and professionals received more than twice as much as agricultural workers" (Szelényi 1978: 69). During the socialist period social stratification increased, expressed by differential access to free or subsidized "fringe" benefits which were associated with occupational stratification and positions in the nomenclature. The upper strata increasingly received "surplus" incomes (Hamilton 1995: 71). Paradoxically, the introduction of economic (market-oriented) reforms such as market regulated prices of certain goods served the interests of the working class more than the nomenclature. "While under capitalism the market creates the basic inequalities and the administrative allocation of welfare modifies and moderates them slightly, under socialism the major inequalities are created by administrative allocation, and the market can be used to reduce inequalities" (Szelényi 1983: 11). The introduction of a centrally planned economy and the power monopoly of the communist party did not abolish social and spatial inequalities, they just changed some of the main forces creating inequality.

The image of "equality in socialism" was constructed by propaganda and the communist monopoly over mass media and over scientific publications, statistics and public education. The change of the political system made it possible to deconstruct the artificial and unjustified image about equality in communist countries. As soon as it was no longer dangerous for a social scientist to talk about poverty, income inequalities, gender inequalities or injustice in socialism, they were openly discussed. Three categories of social inequalities which are not to be expected in communist systems because they contradict the claims of Marxist ideology will be analyzed in the following empirical chapter: the extreme spatial concentration of power and knowledge in the "center", gender disparities in the labor force and the inequalities of ethnic minorities.

\section{Spatial and Social Inequalities in a Communist Labor Market}

\section{The spatial distribution of highly qualified jobs}

In 1980, Budapest, the capital of Hungary,

Table 1. Job concentration for university graduates in Budapest and the capitals of the 19 Hungarian Provinces

Economic branches, Professions

Jobs for university graduates in foreign trade

Jobs for university graduates in personal and business services

Jobs for university graduates in organization and development in

housing

Jobs for university graduates in science and research

Jobs for university graduates in cultural services

Jobs for university graduates in banking and finance

Jobs for university graduates in transport and traffic

Jobs for university graduates in telecommunications

Jobs for university graduates in public administration

Jobs for university graduates in machinery

Jobs for university graduates in light industry

Total population
Proportion of jobs located in Budapest and the capitals of the 19 Hungarian provinces

98.7 percent

96.1 percent

96.0 percent

88.7 percent

88.6 percent

87.8 percent

86.6 percent

86.5 percent

80.3 percent

79.9 percent

74.9 percent

35.0 percent

Source: Unpublished special analysis of the Hungarian Census 1980. 
offered approximately 23 percent of all Hungarian jobs, but almost 50 percent of all Hungarian jobs for university graduates and more than 80 percent of jobs for university graduates in the key branches of the communist system. If the capitals of the 19 provinces are included, then these 20 cities at the top of the urban hierarchy (0.64 percent of all Hungarian cities and villages, 35.4 percent of the population) almost had a monopoly of decision making and skills (Table 1).

Thirty-two percent of the total Hungarian population ( 3.4 million people) resided in 2,838 communities having less than 5,000 inhabitants (90.9 percent of all cities and villages). This community-size class comprised only 7.4 percent of all Hungarian jobs for university graduates. Most of these jobs were in agriculture and forestry (44.2 percent), health services (13.6 percent), education (10.6 percent), economic services (5.0 percent), retail trade (4.9 percent) and mining (4.3 percent). Prestigious, highly qualified jobs important for the communist system were nearly absent in this sizeclass (Table 2).

On the other hand, the sizeclass of less than 5,000 inhabitants offered jobs for 46.2 percent of all Hungarian casual workers (outside agriculture), 60.2 percent of all those employed in agriculture, and 70.9 percent of all jobs for daylaborers in agriculture.

In addition to this spatial polarization of knowledge and skills, large central-peripheral gradients were found with regard to the proportion of university graduates or elementary school leavers among the labor force at their place of work (Figure 2).

The larger the city size, the larger the proportion of university graduates and the smaller the proportion of the lowest educational levels among the work force. In Budapest the proportion of university graduates among the male work force was 7.9 times higher than in the communitysize up to 500 inhabitants; in the female work force it was 25.7 times as high. The largest central-peripheral disparities (gradients) were found in branches important to the system, such as public administration, law and public order, and banking and finance.

The slogan "place matters" had an even higher rating in communist countries than in market economies. Most social benefits were distributed via place of work in communist systems, and only a small proportion of private households possessed a motor-car in rural areas. Therefore, the spatial distribution of jobs contributed significantly to the existence of various other forms of injustices and social inequalities.

\section{Gender inequalities in the labor force}

Gender segmentation Social and spatial disparities in female employment rates are of special interest because the existence of gender inequalities was denied by official publications until the end of communism in Eastern Europe (Meusburger 1995b). Contrary to the communist propaganda about achievements in gender equality, great gender segmentation existed in the Hungarian labor market. In the communist period women were extremely underrepresented in positions of power and

Table 2. The concentration of highly qualified jobs in villages and cities up to 5,000 inhabitants

Professions and occupations of persons with a university degree

Journalists

Leading organs of state power and central administration

Foreign trade

Community services

Banking and finance

Telecommunications

Leaders of party and mass organizations

Law and public order
Proportion of all Hungarian jobs, located in cities and villages up to 5,000 inhabitants

Source: Unpublished data of the Hungarian Census 1980. 
decision-making, and the largest proportion of women worked in the lowest income and skill levels. Among the 14,416 most powerful persons belonging to the communist cadres or the so-called nomenclature in 1987 , the proportion of women was only 16.7 percent (Table 3; Harcsa 1995: 274-275).

The way in which men and women were distributed among the economic branches and the development of gender segmentation in the 1980s benefited women when Hungary introduced a market economy. Women were highly represented in branches that experienced a large expansion in the transformation period, such as banking, retail trade and computing (Table 4). They were also well represented in branches that belonged to the protected labor market, such as education and public administration.

Female labor force participation rates Contrary to official reports of communist systems and widely accepted assumptions in western countries, female employment rates in socialist countries varied strongly according to educational achievement, family status, number of children and area of residence. In socialist Hungary (1980), the employment rates of female university graduates were, depending on their age, 14-26 percent higher than those of females who only completed primary school and 30 to 40 percent higher than those who never attended or completed primary school (Figure

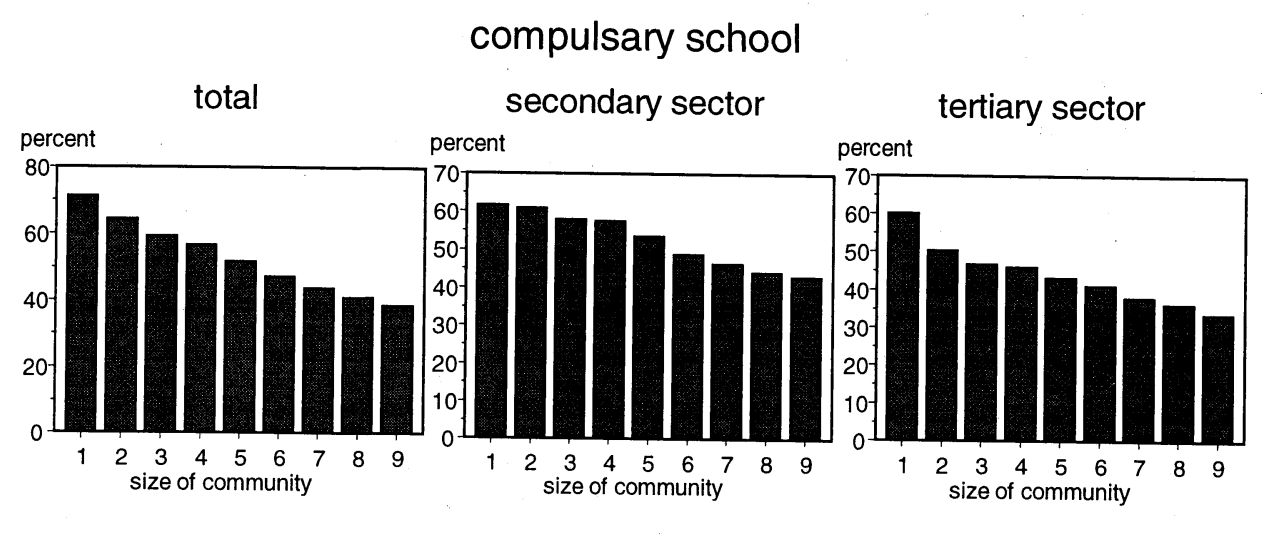

\section{University graduates}

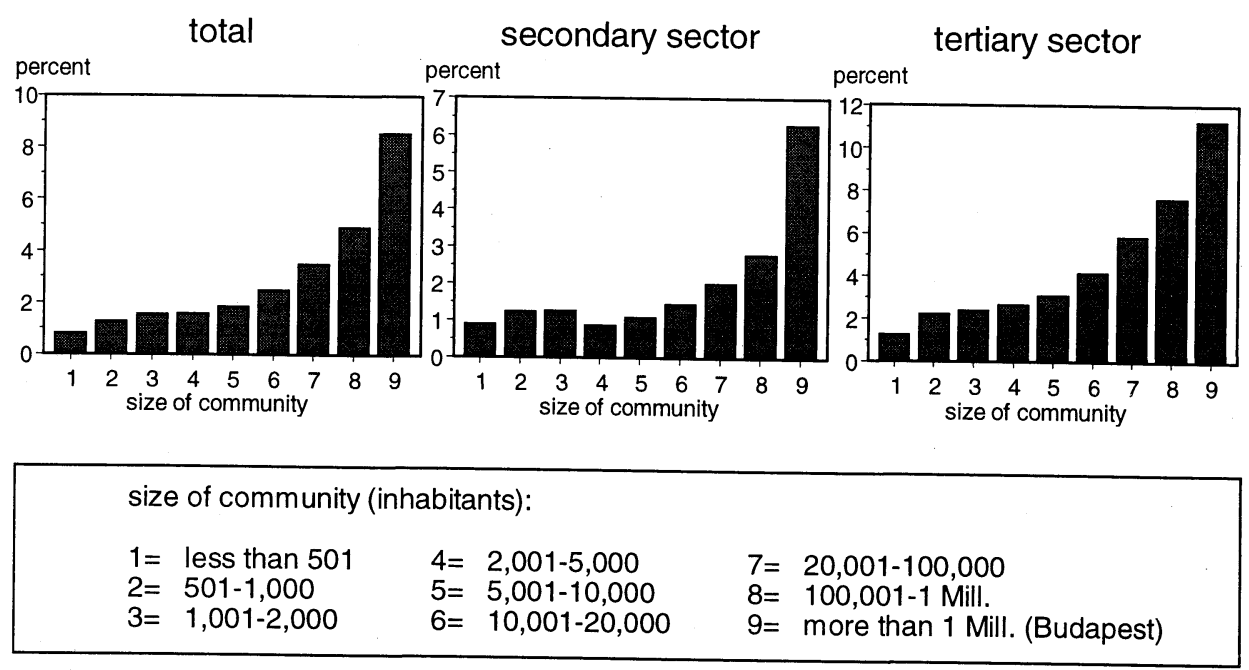

Figure 2. The percentage of compulsary school leavers and university graduates in relation to the size of the communities where the job was located-according to economic sector (1980). 

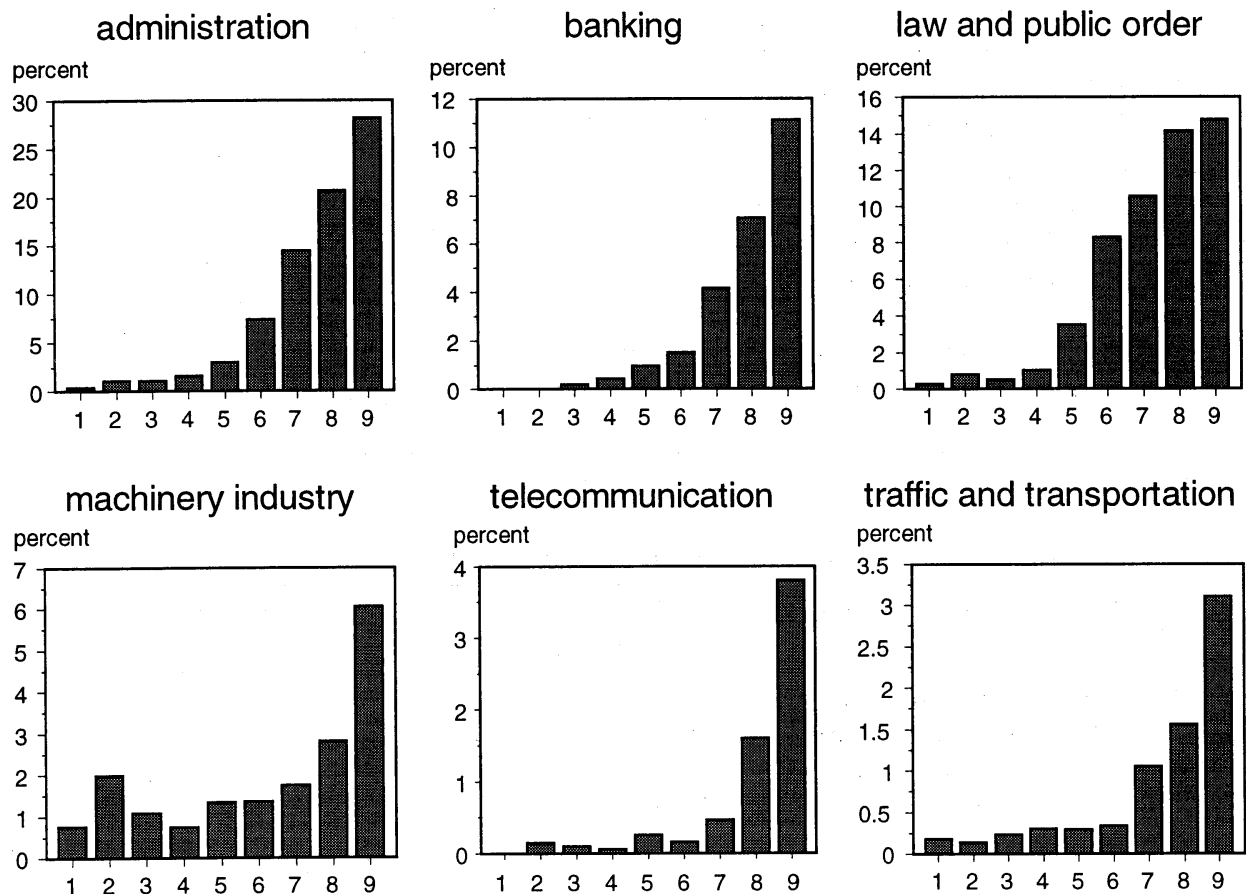
percent
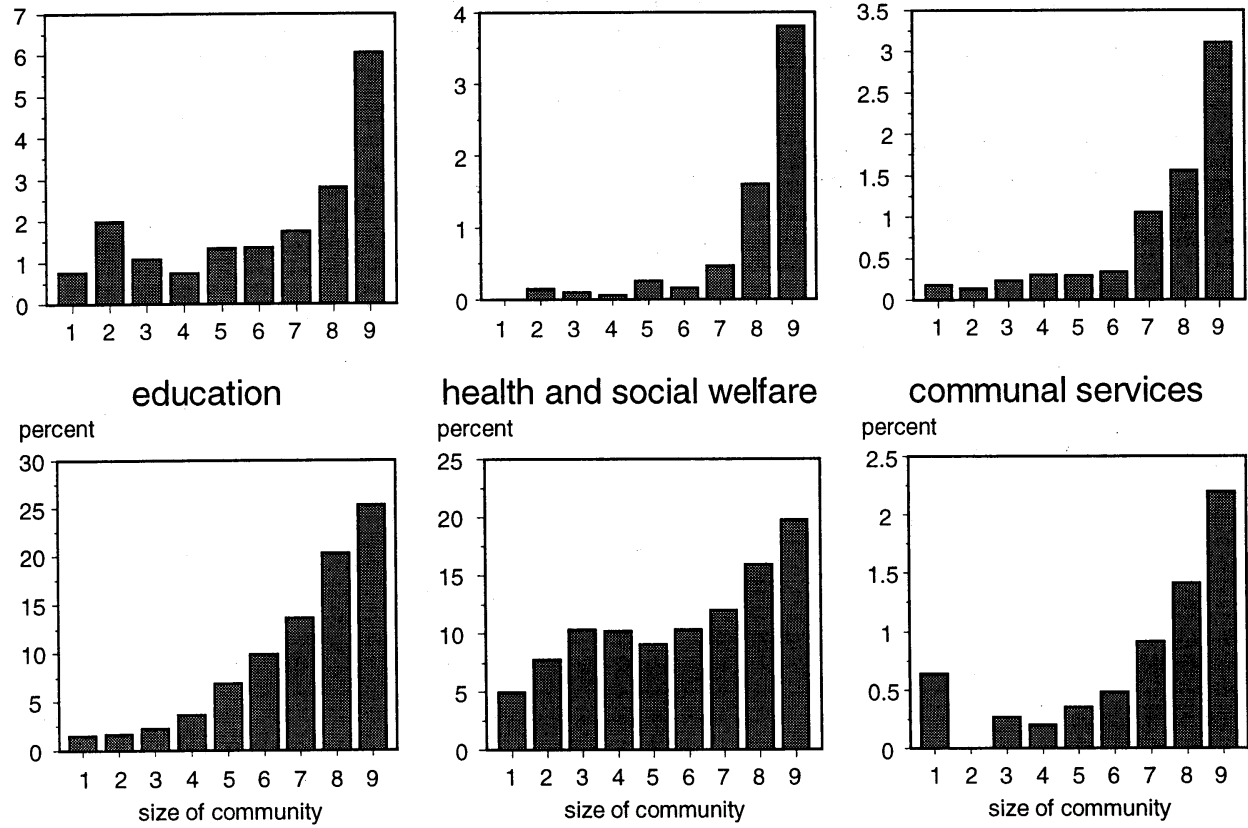

health and social welfare percent
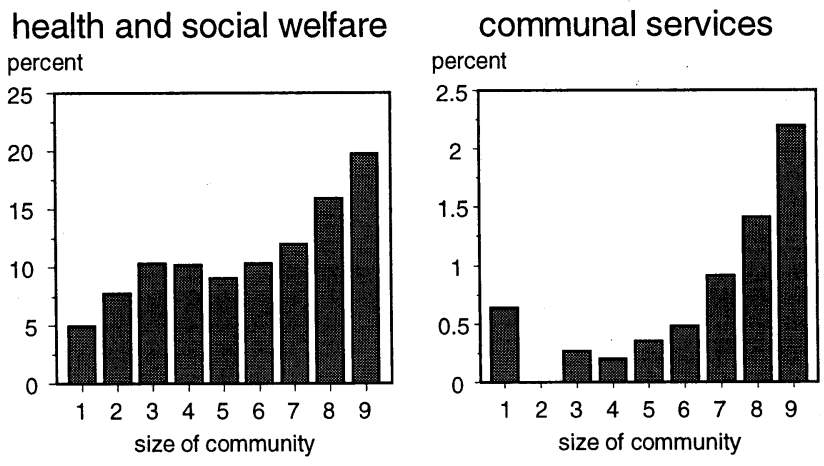

size of community (inhabitants):
$1=$ less than 501
$4=2,001-5,000$
$7=20,001-100,000$
$2=501-1,000$
$5=5,001-10,000$
$8=100,001-1$ Mill.
$3=1,001-2,000$
$6=10,001-20,000$
$9=$ more than 1 Mill. (Budapest)

Figure 2 (continued). The percentage of university graduates in relation to the size of the communities where the job was located-according to selected economic branches (1980).

3). The so-called "child-rearing" phase was much more accentuated in the employment curve of those women who only completed primary school than in the curve of female university graduates. Similar to the situation in western countries, the number of children born greatly influenced the age-specific employment curve of women. Due to the low salaries and the economic squeeze in communist countries, married women had a higher employment rate between 35 and 45 years of age than single women (unpublished data of Hungarian Census 1990; Meusburger 1995b).

In communist times female employment rates showed unexpectedly large regional and central-peripheral disparities. The smaller (and 
Table 3. The proportion of women among selected levels of the Hungarian nomenclature in 1987

\begin{tabular}{lc}
\hline Level of nomenclature & Proportion of women \\
\hline First level of state administration & 0.8 percent \\
First level of agricultural cooperatives & 1.2 percent \\
First level of large industrial state enterprises & 4.4 percent \\
Second level of large industrial state enterprises & 8.8 percent \\
Third level of large industrial state enterprises & 12.7 percent \\
Editors-in-chief in mass media & 11.2 percent \\
Second level of editors in mass media (deputy editors) & 15.7 percent \\
Second level of industrial cooperatives (deputy leaders) & 55.4 percent \\
Total nomenclature & 16.7 percent \\
\hline
\end{tabular}

Source: Harcsa 1995, 274-275.

Table 4. Gender segmentation in the Hungarian Labor Force in 1980

\begin{tabular}{lc}
\hline Selected occupations, professions, economic branches & Proportion of women \\
\hline Technical managers & 6.6 percent \\
Foreman chiefs or shop foremen & 7.4 percent \\
Leaders of production and consumption cooperatives & 7.4 percent \\
Local chiefs of production units & 11.2 percent \\
General directors of state enterprises and institutions & 15.6 percent \\
Leading state organs & 16.3 percent \\
Engineers & 16.4 percent \\
Technical researchers & 25.1 percent \\
Officers of the communist party and of mass organizations & 26.9 percent \\
\hline Professional leaders in computing & 55.9 percent \\
Occupations in printing & 64.0 percent \\
Financial and economic managers & 64.1 percent \\
Managers of service shops & 69.2 percent \\
Banking and finance & 70.8 percent \\
Public education & 73.2 percent \\
Occupations in computer techniques & 76.8 percent \\
Operators in computing and data entry & 84.7 percent \\
Cashiers and booking officers & 90.3 percent \\
Accounting & 91.2 percent \\
Assistants & 97.0 percent \\
\hline
\end{tabular}

Source: Unpublished data of the Hungarian Census 1980.

more rural) the place of residence, the lower the female employment rates and the deeper the so-called "trough" of the child-rearing phase (Figure 4). This retreat from gainful employment was often accompanied by child care support. The proportion of women receiving child care support in 1980 varied with their educational attainment level and showed large central-peripheral disparities. Among female university graduates, a smaller share took child care leave than among those women with lower educational attainment. The smaller the city or village of residence, the higher the share of 2030 year-old women receiving child care support

\section{(Figure 5).}

Contrary to the self-representation of socialist systems, large regional and urban-rural disparities existed with regard to female employment rates. The highest female employment rate (15-55 year-old age group) was in Budapest (77.9 percent) and the lowest percentage of gainfully employed women was in the eastern districts of Hungary, such as Vámospércs with 45.4 percent (Figure 6). The disparities shown in figures 3-6 and tables 3-4 indicate that the communist claim of gender equality, which appeared in the media until the end of the 1980 's, was far from true, especially in rural 
Labor force participation rate (\%)

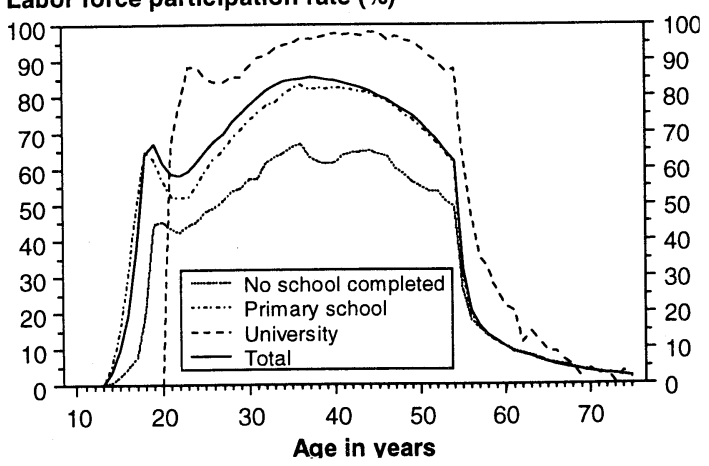

Figure 3. Female labor force participation rates in Hungary (1980) according to age and educational attainment of women.

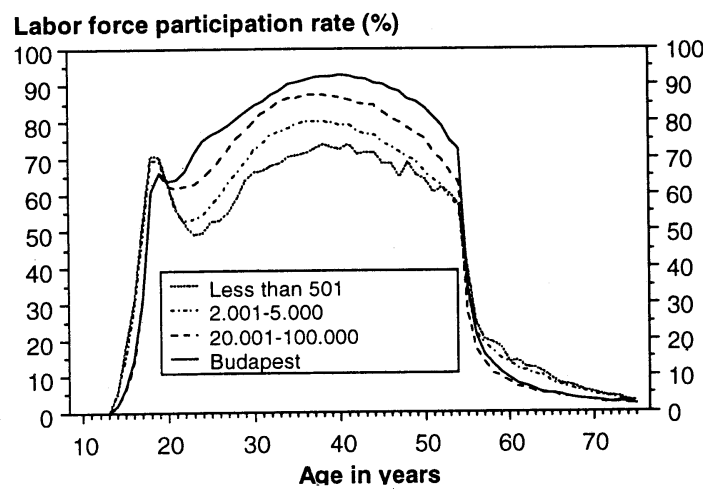

Figure 4. Female labor force participation rates in Hungary (1980) according to age and communitysize of their place of residence.

areas and in regions with an unfavorable economic structure.

\section{Ethnic minorities - the case of the gypsies}

The range of social and spatial inequalities in communist systems can best be shown by studying the situation of highly discriminated minorities. During the orthodox communist period it was very difficult to publish on the discrimination of minorities. Only the change of the political system made it possible to deconstruct the artificial and unjustified image about "equality in communist systems". The key indicators to prove existing inequalities are labor force participation, occupations and educational achievement.

There were large gender-specific disparities

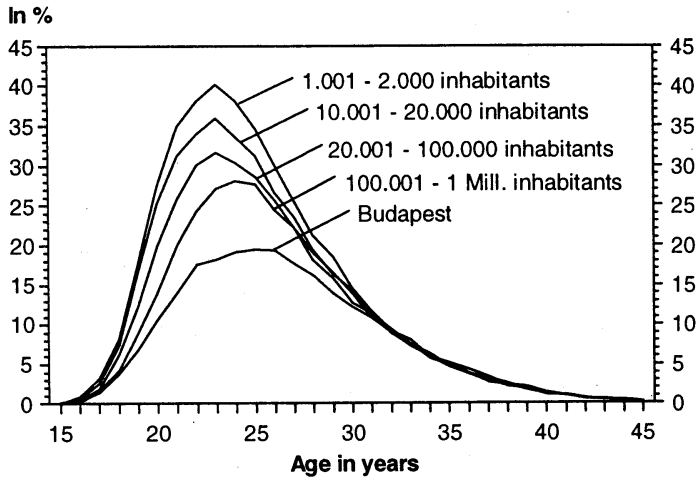

Figure 5. The proportion of women in Hungary (1980) receiving child care support according to age and communitysize class of their place of residence.

among gypsies with regard to labor force participation rates. In 1990 labor force participation rates among female gypsies were $30-50$ percent lower than those for the average of Hungarian women and 30-40 percent lower than those for male gypsies (Figure 7). The child-rearing period is short and clearly visible for Hungarian women as a whole, according to their age-specific employment curves.

The gypsy women's low labor force particiation is due primarily to their low educational attainment, to high fertility and to their usually young age at the birth of their first child. The child-rearing period of gypsy women begins at 16-17 years of age and does not end until $45-50$ years of age. The gypsies have not reached the last post-transformative period of the demographic transition, characterized by low birth and mortality rates seen in Hungary in the beginning of the 1930's (Seewann 1987: 426). The fertility of gypsy women is similar to that of women in developing countries. They generally have their first child at a much younger age and have many more children than other Hungarian women. In 199016.9 percent of all 16 year old gypsies and 29.8 percent of all 17 year old gypsies had at least one child. Among 19 year old gypsy women, 56.7 percent had a child while only 13.9 percent of the total female population had a child (Table 5). Among the 50 year old gypsy women, 50.9 percent had five or more children, but only 3.1 percent of the total female population of the same age had as many 


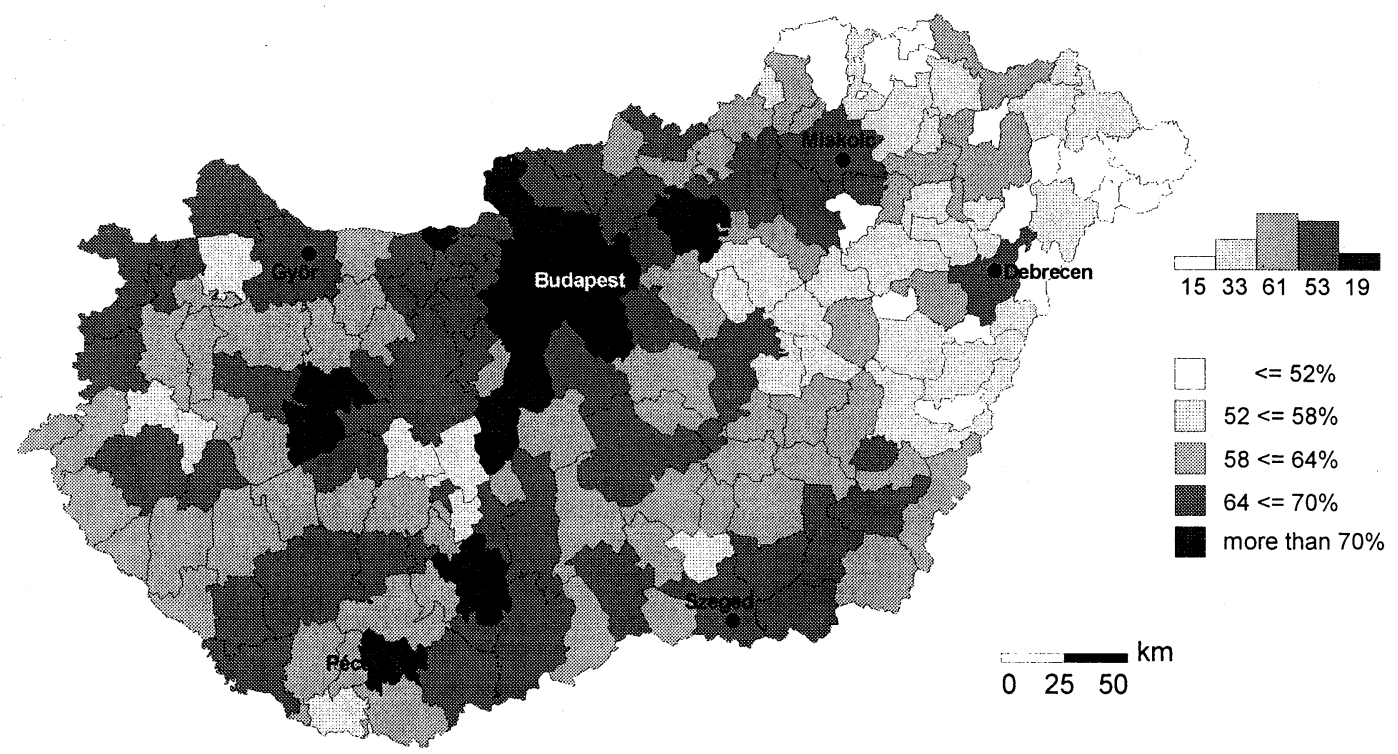

Figure 6. Female labor force participation rates in Hungary (1980).

Labor force participation rate (\%)

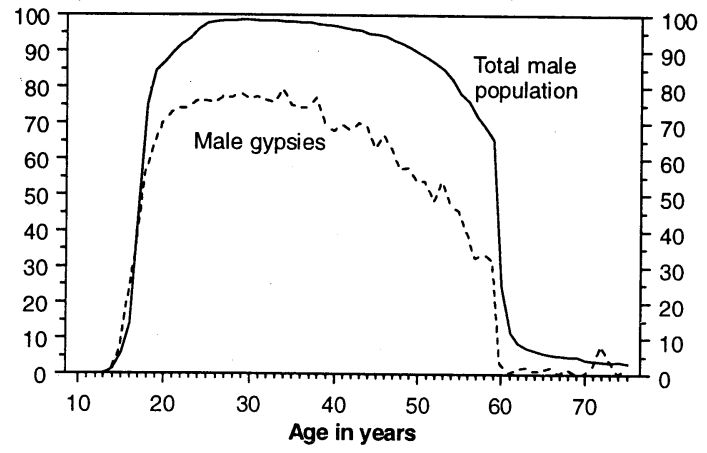

Labor force participation rate (\%)

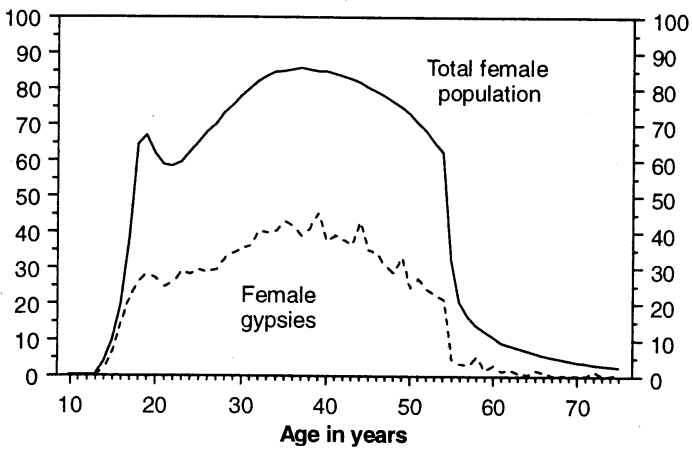

Figure 7. The labor force participation rates of gypsies in Hungary (1990) compared to the total Hungarian populationaccording to gender and age. children. Every fourth 45-50 year old gypsy women and every third gypsy women over fifty had seven or more children.

A bottle-neck for the socio-economic development and the vertical social mobility of gypsies are their high rates of illiteracy and the large proportion of gypsy women who never attended or completed elementary school. In cities and villages below 20,000 inhabitants, two thirds of female gypsies never completed compulsory schooling (Tables 6 and 7), and in peripheral rural areas the share was almost three quarters (72.7 percent).

\section{Consequences of the Transformation Process to Market Economy on Spatial Inequalities}

The fall of the iron curtain, the re-introduction of democracy and of a market economy, and exposure to the global economy altered some of the factors creating social and spatial inequality, the value system of individuals, the value of commodities, the perception and evaluation of space, the value and prestige of locations, the power relations between center and periphery, the goals of regional policy, the economic relations between firms, the system of state subsidies and the recruitment of elites.

"Socialist values" such as production ir- 
Table 5. The number of children born to Hungarian women with regard to the mothers age and ethnicity

\begin{tabular}{|c|c|c|c|c|c|c|}
\hline \multirow[b]{2}{*}{$\begin{array}{l}\text { Women's } \\
\text { Age }\end{array}$} & \multicolumn{2}{|c|}{$\begin{array}{l}\text { Proportion of women with } \\
\text { one child or more }\end{array}$} & \multicolumn{2}{|c|}{$\begin{array}{l}\text { Proportion of women with } \\
\text { three or more children }\end{array}$} & \multicolumn{2}{|c|}{$\begin{array}{l}\text { Proportion of women with } \\
\text { five or more children }\end{array}$} \\
\hline & $\begin{array}{c}\text { All } \\
\text { women }\end{array}$ & $\begin{array}{l}\text { Gypsy } \\
\text { women }\end{array}$ & $\begin{array}{c}\text { All } \\
\text { women }\end{array}$ & $\begin{array}{l}\text { Gypsy } \\
\text { women }\end{array}$ & $\begin{array}{c}\text { All } \\
\text { women }\end{array}$ & $\begin{array}{l}\text { Gypsy } \\
\text { women }\end{array}$ \\
\hline 15 years old & 0.55 & 5.80 & . & . & . & . \\
\hline 16 years old & 1.61 & 16.91 & 0.03 & 0.12 & . & . \\
\hline 17 years old & 3.69 & 29.81 & 0.03 & 0.48 & . & . \\
\hline 18 years old & 7.65 & 45.63 & 0.09 & 1.66 & . & . \\
\hline 19 years old & 13.92 & 56.69 & 0.25 & 4.53 & . & . \\
\hline 20 years old & 23.56 & 67.10 & 0.59 & 8.19 & 0.02 & 0.29 \\
\hline 25 years old & 70.10 & 86.86 & 5.51 & 39.44 & 0.28 & 5.42 \\
\hline 30 years old & 87.14 & 92.50 & 13.25 & 56.66 & 1.05 & 16.06 \\
\hline 35 years old & 90.69 & 92.88 & 16.69 & 65.14 & 1.30 & 21.11 \\
\hline 40 years old & 91.71 & 94.58 & 19.72 & 72.53 & 2.17 & 37.78 \\
\hline 45 years old & 91.30 & 95.39 & 18.69 & 78.15 & 2.31 & 49.89 \\
\hline 50 years old & 90.83 & 94.23 & 18.98 & 79.53 & 3.14 & 50.90 \\
\hline
\end{tabular}

Source: Special analysis of the Hungarian Census 1990.

Table 6. The educational attainment of Hungarian gypsies above 14 years of age in 1990 with regard to the size of their place of residence

\begin{tabular}{lcccccc}
\hline & \multicolumn{5}{c}{ Highest level of educational attainment completed } \\
\hline $\begin{array}{c}\text { Community size- } \\
\text { number of residents }\end{array}$ & $\begin{array}{c}\text { No school } \\
\text { completed }\end{array}$ & $\begin{array}{c}\text { Elementary } \\
\text { school }\end{array}$ & $\begin{array}{c}\text { Vocational } \\
\text { school }\end{array}$ & $\begin{array}{c}\text { Intermediate } \\
\text { school }\end{array}$ & $\begin{array}{c}\text { Secondary } \\
\text { school }\end{array}$ & University \\
\hline up to 500 & 63.26 & 32.68 & 3.78 & 0.04 & 0.22 & 0.02 \\
$501-1.000$ & 59.67 & 35.82 & 4.07 & 0.07 & 0.36 & 0.02 \\
$1.001-2.000$ & 56.80 & 38.73 & 4.06 & 0.05 & 0.33 & 0.09 \\
$2.001-5.000$ & 57.92 & 37.97 & 3.65 & 0.03 & 0.39 & 0.04 \\
$5.001-10.000$ & 55.31 & 39.87 & 4.08 & 0.04 & 0.63 & 0.07 \\
$10.001-20.000$ & 57.43 & 37.96 & 3.82 & 0.09 & 0.60 & 0.11 \\
$20.001-100.000$ & 52.25 & 41.22 & 5.45 & 0.07 & 0.86 & 0.16 \\
$100.001-1$ million & 44.15 & 47.52 & 6.18 & 0.15 & 1.75 & 0.24 \\
Budapest & 33.54 & 54.86 & 7.05 & 0.28 & 3.55 & 0.71 \\
Hungary total & 54.97 & 39.71 & 4.39 & 0.07 & 0.74 & 0.11 \\
\hline
\end{tabular}

Source: Special analysis of the Hungarian Census 1990; Oesterer und Meusburger 1998.

Table 7. The proportion of Hungarian gypsies (14 years and older) who have not completed compulsory schooling with regard to the size-class of their place of residence

\begin{tabular}{ccc}
\hline City size-number of residents & Male gypsies & Female gypsies \\
\hline up to 500 & 53.60 & 72.71 \\
$501-1000$ & 50.36 & 68.73 \\
$1001-2000$ & 48.52 & 64.80 \\
$2001-5000$ & 49.18 & 66.28 \\
$5001-10000$ & 45.86 & 64.74 \\
$10001-20000$ & 48.66 & 66.13 \\
$20001-100000$ & 42.83 & 62.03 \\
$100001-1$ million & 33.35 & 54.70 \\
Budapest & 26.27 & 42.42 \\
\hline
\end{tabular}

Source: Special analysis of the Hungarian Census 1990; Oesterer und Meusburger 1998. 
respective of cost and consumer preferences, full employment, etc. were abandoned in favor of capitalist values such as efficiency, quality, profit and competitiveness. Ideological liability and faithfulness to the party lost their value as recruiting instruments of the elite in favor of skills, qualification, experience and competence. Furthermore, the fall of the "iron curtain", the introduction of the market economy, the abolition of central planning, and the restitution of political and financial autonomy to the cities and communes fundamentally altered the evaluation of space, place, city and region with respect to the location, functioning and reorganization of productive activities (Cséfalvay 1995a, 1995b; Hamilton 1995: 69). Cities and regions no longer waited for the allocation of resources by the central administration, but competed with each other for national and foreign investment. Previous policies hindering indigenous development were removed and subsidies preventing the collapse of uncompetitive firms were reduced. Contacts with and relations to foreign firms and institutions were no longer the exclusive monopoly of central institutions of the state. Any region, city or firm could take advantage of opportunities.

This indicates that the transformation process combines two diverse trends, a positive one, creating jobs, and a negative one, destroying jobs. The negative trend started in the northeastern and eastern regions of Hungary which were even classified as crisis regions in socialist times. This trend is characterized by the crisis of the state sector, the decline of heavy industry and mining, the collapse of state-owned and heavily subsidized firms, the collapse of the formerly safe export markets in the COMECON, de-industrialization, the decrease of industrial and agricultural production, the dissolution of the "state-controlled labor market", the dismissal of unneeded labor and the fast growth of unemployment until 1993. Some of the "new socialist cities" which were heavily supported by state subsidies during the socialist period were also affected by high unemployment. For political and financial reasons, the structural problems in heavy industry, mining and unproductive agriculture could not be solved and the surplus of un- needed labor (20 percent) could not be dismissed during the socialist period. After the introduction of the market economy, formerly hidden unemployment ("unemployment behind the factory doors") became real and more intense (Fassmann 1995; Dövényi 1995).

However, there is a positive trend occurring, consisting of new firm formation, reorganization and privatization of competitive statefirms, joint venture formation, foreign capital investment, expansion of the service sector, creation of new and preservation of existing jobs, modernization of industry and agriculture and the creation of new institutions (e.g. banking system), all of which are necessary for a market economy. This positive change first took place in those areas where the necessary knowledge, skills, creativity, experience and information were available and not where neoclassical economic theory would have expected. Human resources which were able to cope with the new situation were concentrated in the capital city of Budapest and in the largest 3-5 provincial capitals, where the competent decision-makers of the old system were working and where the nomenclature used their good connections and international relations to profit from the new developments. Members of the old nomenclature took advantage of their privileged positions and their networks to assume private ownership of state property and to turn themselves into "capitalists". They easily found either a loophole in the newly established economic law or a legal way to accept privatization loans from the government to buy up their own or other state enterprises.

The second areas to profit from the transformation process were the northwestern parts of Hungary, especially the northern parts of Transdanubia, which had historically been the door for various innovations, as was mentioned before. Re-industrialization, mostly through foreign investment and joint ventures, started in the metropolitan area of the capital and in the western parts of Hungary, predominantly in the industrial districts of Székesfehérvár, Györ, Esztergom and Szentgotthard. In the cities and regions of Northern Transdanubia, civic traditions and entrepreneurial skills partly survived the communist period and 
became a stimulus for indigenous development. As soon as the rigid communist system introduced the first economic reforms and became more liberal, the capital of Budapest and the northern parts of Transdanubia immediately took advantage of the new opportunities created by liberalization. In the $1980 \mathrm{~s}$, these areas had the highest density of "voluntary economic associations", an officially tolerated form of semi-private organizations. These "voluntary economic associations" produced on market terms, but were allowed to use the equipment and machines of the state firms and cooperatives where they were employed. In this way they gained experience with a kind of proto-market economy. After the fall of the iron curtain the agglomeration of Budapest and parts of Transdanubia attracted many joint ventures and the greatest proportion of foreign capital. Therefore, in 1995 they had the lowest rates of unemployment and the highest density of limited liability companies, indicating that the reorganization and privatization of the economy progressed quickly in these regions.

After the fall of the iron curtain, these parts of Transdanubia profited a great deal from their close proximity to Austria (Vienna), from weekend tourism of Austrian citizen, from crossborder shopping and cross-border commuting caused by the large wage and price gaps along the border. A number of Hungarian towns and villages in Transdanubia had a German minority (some of them even a majority), since the end of Turkish occupation in 17 th century. They could use their old contacts to relatives and former German refugees in order to establish joint ventures with Austrian or German entrepreneurs or to establish sales offices in foreign countries. The advantages which large cities and western border areas had was also supported by the fact that cities in the western half of Hungary (one or two hours from Vienna) attracted foreign firms who wished to establish sales offices or services in a newly emerging market. These cities also profited from more rapid and easier privatization in the service sector (retail shops, tourism, business services, consulting), primarily because the capital and space requirements for modernizing existing or introducing new services were relatively modest (Hamilton 1995: 73). The western regions of Hungary were also at an advantage because apart from a few exceptions during the communist period, border zones along the iron curtain did not attract major industrial investments. They were considered strategically vulnerable, bristled with defense installations and facilities, and the government did not want to attract migrant labor close to the western border for fear of large-scale "defections" to the west (Hamilton 1995: 74). Therefore, in the 1980 's and 1990's these areas did not suffer as much from de-industrialization as the statesubsidized cores of heavy and chemical industries in central and eastern Hungary (Dunaujvaros, Miskolc, Ózd, etc.).

Cséfalvay (1995c) showed that the marked separation between western and eastern Hungary was caused by internal and external factors. By combining positive and negative internal and external factors, he classified four regional types. Type I had positive internal and external factors and was restricted to the northern part of Transdanubia along the transport axis to Vienna. Type II enjoyed favorable internal factors, but was not attractive to the first wave of foreign investment. Type III showed a negative internal situation, but seemed to be attractive to foreign investment. Type IV was handicapped by unfavorable internal and external influences and suffered from the devaluation of the eastern border areas.

Since these two controversial trends started in different areas, they increased the longstanding economic and social dichotomy between western and eastern Hungary and strengthened the primate city effect of Budapest during the first years of transformation (Cséfalvay 1995b). The gap or dichotomy between western and eastern Hungary can be illustrated by foreign investment, density of joint ventures, density of limited liability companies, unemployment rates, per capita taxable income, an increase or decrease in the number of jobs, the qualification of the labor force, the high proportion of selfemployment and many other indicators.

\section{Conclusion}

The transformation process towards a mar- 
ket economy has reduced some of the inequalities and disparities existing in communist system (e.g. gender gap in labor force participation, central-peripheral disparities in certain kinds of infrastructure) but has enlarged other inequalitites (e.g. per capita income, west-east disparities). Transdanubia belonged to the winners of market economy, the North-eastern parts of Hungary to the losers (Nemes-Nagy 1994; Cséfalvay, Fassmann und Rohn 1993; Cséfalvay 1994, 1995a, 1995b). Cséfalvay (1995b) has described three scenarios concerning the future development of spatial disparities in Hungary. According to the socalled "iron-curtain" scenario, the east-west differentiation becomes the key element of regional processes. While rapid development can be observed along the western border, a new "iron curtain" arises simultaneously in the eastern part towards Ukraine. The so-called "Latin American" scenario emphasizes the increasing concentration of investment and growth, which leads to a duality between the overdomination of Budapest and total underdevelopment of a large part of the rural areas. According to the "Austrian Empire" scenario, Transdanubia and the agglomeration of Budapest will be integrated into the Austrian-North Italian-South German growth area, whereas the rest of Hungary will be handicapped in its development. The question of which of these 3 scenarios will have the highest probability depends largely on external factors, such as the political and economic development and spatial extension of the European Union, the future relationship between the European Union and the GUS states, and the political situation in the Balkans.

(Received Mar. 29, 1997)

(Accepted Oct. 10, 1997)

\section{References}

Andorka, R. 1976. Tendencies of Regional Development and Differentiation in Hungary, Measured by Social Indicators. Central Statistical Office, Budapest (mimeo).

Bakunin, M. 1984. Sozialismus und Freiheit. Berlin: Libertad Verlag, 5th edition.

Bleek, W. und L. Mertens 1994: DDR-Dissertationen. Promotionspraxis und Geheimhaltung von Doktorarbeiten im SED-Staat. Opladen: Westdeutscher Verlag.
Braverman, H. 1974. Labor and Monopoly Capital. New York: Monthly Review Press.

Burawoy, M. 1989. Reflections on the Class Consciousness of Hungarian Steelworkers. Politics \& Society 17: 1-34.

Burawoy, M. 1990. Marxism is Dead, Long Live Marxism. Socialist Review 90 (2): 7-19.

Corbridge, St. 1989. Marxism, post-Marxisms, and the geography of development. In: New Models in Geography, vol. 1, ed. R. Peet and N. Thrift, 224254. London: Unwin Hyman,

Cséfalvay, Z. 1994. The Regional Differentiation of the Hungarian Economy in Transition. GeoJournal 32: 351-362.

Cséfalvay, Z. 1995a. Östmitteleuropa im Umbruch. In: Von der Planwirtschaft zur Marktwirtschaft. Eine Untersuchung am Beispiel Ungarns, ed. P. Meusburger und À. Klinger, 19-28. Heidelberg: Physica.

Cséfalvay, Z. (1995b): Raum und Gesellschaft Ungarns in der Übergangsphase zur Marktwirtschaft. In: Von der Planwirtschaft zur Marktwirtschaft. Eine Untersuchung am Beispiel Ungarns, ed. P. Meusburger und À. Klinger, 8098. Heidelberg: Physica.:

Cséfalvay, Z. 1995c. Fünf Jahre Transformation des ungarischen Arbeits- und Wohnungsmarktes. In Immobilien-, Wohnungs- und Kapitalmärkte in Ostmitteleuropa. Beiträge zur regionalen Transformationsforschung, ed. H. Fassmann, 87-103. ISR-Forschungsberichte 14, Wien: Österreichische Akademie der Wissenschaften.

Cséfalvay, Z., Fassmann, H. und W. Rohn 1993. Regionalstruktur im Wandel-Das Beispiel Ungarn. ISR-Forschungsberichte 11, Wien: Österreichische Akademie der Wissenschaften.

Dövényi, Z. 1995. Die strukturellen und territorialen Besonderheiten der Arbeitslosigkeit in Ungarn. In: Von der Planwirtschaft zur Marktwirtschaft. Eine Untersuchung am Beispiel Ungarns, ed. P. Meusburger und À. Klinger, 114-129. Heidelberg: Physica.

Fassmann, H. 1995. Wegbegleiter nach Europa: Ökonomische Krisen und wachsende Arbeitslosigkeit in Ost-Mitteleuropa. In: Von der Planwirtschaft zur Marktwirtschaft. Eine Untersuchung am Beispiel Ungarns, ed. P. Meusburger und À. Klinger, 1-18. Heidelberg: Physica.

Gentsch, L. 1992. Realsozialismus und Karl Marx. Die Stalinismus-Legende. Frankfurt a.M., etc.: Lang.

Görlich, E. J. 1965. Ungarn. Nürnberg: Glock und Lutz.

Hamilton, I. F. E. 1995. Re-evaluating Space: Locational Change and Adjustment in Central and Eastern Europe. Geographische Zeitschrift 83: 6786.

Harcsa, I. 1995. Ungarische Kader in den Achtziger Jahren. In: Von der Planwirtschaft zur Marktwirtschaft. Eine Untersuchung am Beispiel 
Ungarns, ed. P. Meusburger und À. Klinger, 270284. Heidelberg: Physica.

Harvey, D. 1973. Social justice and the city. London: E. Arnold.

Harvey, D. 1977. The geography of capitalist accumulation: a reconstruction of the Marxian theory. In Radical geography, alternative viewpoints on contemporary social issues, ed. R. Peet, 263-292. London: Methuen.

Harvey, D. 1985. The Urbanization of Capital. Studies in the History and Theory of Capitalist Urbanization. Oxford: Blackwell.

Konrád G. and I. Szelényi 1978. Die Intelligenz auf dem Weg zur Klassenmacht. Frankfurt a. M.: Suhrkamp.

Lengyel G. 1995. Kader und Manager. Unterschiedliche Muster der Rekrutierung von Führungskräften in der Planwirtschaft. In: Von der Planwirtschaft zur Marktwirtschaft. Eine Untersuchung am Beispiel Ungarns, ed. P. Meusburger und À. Klinger, 249-269. Heidelberg: Physica.

Meusburger, P. 1995a. Wissenschaftliche Fragestellungen und theoretische Grundlagen der Geographie des Bildungs- und Qualifikationswesens. Beiträge zur regionalen Bildungsforschung. Münchener Geographische Hefte 72: 53-95.

Meusburger, P 1995b. Zur Veränderung der Frauenerwerbstätigkeit in Ungarn beim Übergang von der sozialistischen Planwirtschaft zur Marktwirtschaft. In: Von der Planwirtschaft zur Marktwirtschaft. Eine Untersuchung am Beispiel Ungarns, ed. P. Meusburger und À. Klinger, 130-181. Heidelberg: Physica.

Mickiewicz E. 1973. Handbook of Soviet Social Science Data. New York: The Free Press; London: Collier Macmillan.

Nemes Nagy, J. 1994. Regional disparities in Hungary during the period of transition to a market economy. GeoJournal 32: 363-368.

Oesterer, M. und P. Meusburger 1998 (in print). Das Ausbildungsniveau und Bildungsverhalten der ungarischen Zigeuner zu Beginn der 90er Jahre. In: Berliner Geographische Abhandlungen.

Peet, R. 1977a. The development of radical geography in the United States. In: Radical geography, alternative viewpoints on contemporary social issues, ed. R. Peet, 6-30. London: Methuen.

Peet, R. 1977b. Inequality and poverty. In Radical geography, alternative viewpoints on contemporary social issues, ed. R. Peet, 112-123. London: Methuen.

Peet, R. 1991. Global capitalism. Theories of societal development. London and New York: Routledge.

Pickles J. 1995. Restructuring State Enterprises: Industrial Geography and Eastern European Transitions. Geographische Zeitschrift 83: 114131.

Schroeder G. 1973. Regional Difference in Income and Levels of Living in the USSR. In: The Soviet Economy in Regional Perspective, ed. V. N. Bandera and Z. L. Melnyk. New York: Praeger.

Seewann, G. 1987. Zigeuner in Ungarn. Südosteuropa 36: $19-32$.

Smith, D. M. 1979. Where the Grass is Greener. Geographical Perspectives on Inequality. London: Croom Helm.

Smith, D. M. 1987. Geography, inequality and society. Cambridge: University Press.

Smith, D. M. 1994. Geography and social justice. Oxford: Blackwell.

Szelényi, I. 1978. Social inequalities in state socialist redistributive economies. International Journal of Comparative Sociology 19: 63-87.

Szelényi, I. 1983. Urban inequalities under state socialism. Oxford: Blackwell.

Szelényi, I. and B. Martin 1988. The three waves of New Class theories. Theory and Society 17: 645667.

Wallerstein, I. 1979. The capitalist world economy. Cambridge: University Press.

Zwick P. 1976. Intrasystem Inequality and the Symmetry of Socioeconomic Development in the USSR. Comparative Politics 8: 501-524. 